Available online at TARBIYA: Journal of Education in Muslim Society Website: http:/ /journal.uinjkt.ac.id/index.php/tarbiya

TARBIYA: Journal of Education in Muslim Society, 2(2), 2015, 146-152

\title{
TEACHER PROFESSIONAL DEVELOPMENT AND APPRAISAL
}

\author{
Kushtarbek Kimshanov ${ }^{1}$, Totukan Dyikanbaeva², \\ ${ }^{\prime}$ Osh Town Education Department, Kyrgyzstan \\ ${ }^{2}$ Osh State University, Kyrgyzstan \\ E-mail: ${ }^{1}$ Kkimsanov@mail.ru, ${ }^{2}$ totukan.dyikanbaeva@mail.ru,
}

Received: $12^{\text {th }}$ November 2015; Revised: $05^{\text {th }}$ December 2015; Accepted: $28^{\text {th }}$ December 2015

\section{Abstract}

The paper is based on analysis of international literature on school teacher appraisal and professional development. Teacher appraisal is a very important area of study, and traditionally it has been quite a contested field as well. Teachers used to feel tension and anxiety due to unfair teacher appraisal, and they often reacted to teacher appraisal with resentment and nervousness. Historically, teacher teacher appraisal was aimed to inform the issues and training considerations in education during the decades of the seventies and was establish to exercise greater accountability to maintain a high standard in education. However, eventually the developmental purpose had been emphasized. This paper presents rich literature on teacher appraisal and teacher development concepts.

Keywords: teacher appraisal; professional development; teacher evaluation; teacher performance

\section{Abstrak}

Artikel ini berdasarkan analisis literatur internasional pada penilaian guru sekolah dan pengembangan profesional. Penilaian guru merupakan bidang kajian yang sangat penting, dan sudah menjadi bidang kajian yang cukup sering diperdebatkan. Guru kerap merasa tegang dan cemas dikarenakan penilaian guru yang tidak adil, dan mereka sering bereaksi terhadap penilaian guru dengan kekesalan dan gugup. Dalam sejarahnya, penilaian guru bertujuan untuk memberitahukan isu-isu dan pertimbangan pelatihan dalam pendidikan selama dekade tujuh puluhan dan telah dibentuk untuk melatih akuntabilitas yang lebih baik untuk mengatasi standar pendidikan yang tinggi. Namun, akhirnya tujuan pengembangan telah ditekankan. Artikel ini memberikan beragam informasi tentang penilaian guru dan konsep pengembangan guru.

Kata Kunci: penilaian guru; pengembangan profesional; evaluasi guru; kinerja guru

How to Cite : Kimshanov, K., Dyikanbaeva, T. (2015). Teacher Professional Development and Appraisal. TARBIYA: Journal Of Education In Muslim Society, 2(2), 146-152. doi:10.15408/tjems.v2i2.2802.

Permalink/DOI: http://dx.doi.org/10.15408/tjems.v2i2.2802 


\section{Introduction}

This paper is about teacher performance appraisal (TPA), which is a vital part of the education process. One of the authors is a head of town education department, teacher appraisal is one of the key responsibilities that education officials are assigned to do among many other tasks. Appraisal in general sense is about making of judgments about the worth or a value of a phenomenon in terms of agreed upon criteria such as a goal (Dimmock, 2000). Thus teacher appraisal serves to evaluate teachers' performance against a goal agreed by mutual understanding between the appraiser and appraisee. Hence, it has a potential to bring improvement in the quality of teachers' performance through which the school can accomplish its goal.

\section{Definitions of Teacher Appraisal}

If we look at the history of teacher appraisal, the formal application of teacher performance appraisal started in United Kingdom in order to inform the issues and training considerations in education during the decades of the seventies (Poster \& Cyril, 1994). In the first place, TPA aimed to exercise greater accountability to maintain a high standard in education. However, later on, the developmental purpose had been emphasized. Thus, two main underlying philosophies led to different directions, one stresses on accountability, while the other emphasizes on professional development (Newton, 1996).

TPA helps in identifying the gaps and training needs of teachers for further development in order to meet the standards of teaching and learning (Smith, 2002). It provides opportunities for professional development through reflection and feedback, collaboration, involving the exchange of ideas and mutual support. According to Newton (1996) TPA is a tool for employee's improvement, setting targets, evaluating strengths and finding areas, where more training improves the quality of his/her work and performance. Studies indicate that improved performance leads to improved learning, which results in greater motivation and job satisfaction (Bush \& Middlewood, 2005).

At the same time, TPA can serve as a motivational tool and as Monyatsi (2006) argues, "It was succinctly revealed that if properly done, appraisal could be a very effective intervention in motivating teachers in the schools to improve their performance in teaching and facilitating students' learning"(p.106). To make the appraisal effective, it must be accepted by all those involved in the rigorous and developmental process (Fleming \& Max, 2001). Teachers should be engaged in planning, policy making, setting achievable targets and goals, sharing the criteria and giving constructive appraisal feedback can motivate teachers towards their job.

TPA is seen as tool for identifying training and professional development needs. Through which, teachers can get the opportunities to improve their teaching and learning in order to accomplish the school's mission; and according to relevant literature, improved performance leads towards motivation. If TPA is nestled with the purpose of accountability, exercising with strict control over the domain of teachers' activities can de-motivate teachers. Scholars as Geraldine (1997) and Lunenburg (1999) argue that TPA is a process of collecting data on teachers' performance for the purpose of determining pay level, dismissal, and disciplinary actions. In many contexts TPA is perceived mostly for accountability or managerial purposes, in which certain decisions are taken to promote or demote or even suspend teachers from their job. Hence, it develops suspicion and feelings of de-motivation among teachers. Teachers are thus fearful of the use of appraisal 
as a judgmental mechanism on their practices (Sawatzki, 2005).

TPA thus may vary from context to context, if it is applied effectively that is, empowering teachers in their work domain and giving them opportunities to develop personally and professionally, could motivate teachers to perform better. These conclusions lead us to believe that there is no one universal theory and practice of TPA. Different practitioners in different parts of the world see TPA differently.

\section{Major Purposes of Teacher Appraisal}

As mentioned above, TPA serves two major purposes which are accountability-oriented and improvement-oriented (Stronge, 2006). It is implied in the study that the purpose of improvement oriented TPA is to bring improvement in teachers' professional knowledge, skills and attitudes by identifying the gaps in teaching through the process of TPA. Holly (1990) asserts that TPA serves to promote professional practices through reflections, removal of isolation and enhancement of communication skills and promotion of professional culture in order to enhance students' learning outcomes. TPA makes teachers aware and helps to improve their confidence and competence by promoting a collaborative learning culture in the school.

One of the purposes of TPA is to identify outstanding teachers to give them meritincrement, so that teachers could be motivated to perform better as well. Researchers have found different views of performance-based increment. Harvey-Beavis (2003) states that, "One of the largest benefits reported by proponents of performance-based increment is an increase in the motivation of teachers" (p.7). Nevertheless, it is not necessary that performance-based increment always elicit teachers' motivation. It may motivate some teachers; but that motivation could be for shorter period of time, which may no longer be in the interest of the organization. Similarly, performance-based increment would also fail to motivate teachers on a significant scale (Richardson, 1999). National Union of Teachers (cited in Bell, 1988) elaborates that better teachers deserve higher pay and that the appropriate process for identifying the high quality teachers is through staff appraisal.

TPA is thus often linked with increment pay, which has its impact on teachers' motivation in a different manner. For some teachers, performance-based increment is a source of motivation, while a great deal of teachers feels dissatisfied with linking meritincrement with performance. According to research, a small number of teachers agree that performance-based pay increase influence their motivation in a positive way; while the rest are not happy with appraisal scheme linking performance with salary increment (Richardson, 1999). Hence, it fails to motivate a large number of teachers to work harder and more effectively.

Sometimes, TPA is also used as a means to punish and terminate poor performing teachers from their job. Mishra (2007) argues that in the process of accountability, TPA is used as a means to identify failure and provision is made for removal of a low performing teacher from their service. He also explains that in some of the developing countries, like Indonesia, lesser assignments are given to the low performing teachers rather than dismissing them from the service altogether.

This discussions indicate that TPA serves different purposes such as; professional development of teachers; giving merit increment; career building; and dismissal of low performing teacher from their service. 


\section{Teacher Performance Appraisal}

I now shift the discussion to the processes of teacher performance appraisal. Planning is the first process in the establishment of TPA scheme. According to Hilcox and Musella (cited in Bosetti, 1994):

"In the planning process of TPA, a greater voice should be given to teachers and that the accountability element in appraisal to be reduced by placing more emphasis on key staff development principal i.e. peer coaching, mentoring reflective decision making, collegial support network rather than a subordinate review (p.227).”

Adding to this, Rhodes and Bell (1996) observe that all staff members should be involved in the initial discussions about the proposed procedure and should be given the opportunity to react and express their fears and reservations. They further comment that appraisal is a sensitive issue, which needs to be carried out delicately and with staff cooperation.

During the TPA, data can be collected through classroom observation, peer appraisal and evidences gathered through student achievements.

\section{Classroom Observation}

Classroom observation provides the major part of evaluating teachers' performance, as the main duty of a teacher is his/her classroom practices. Smith (2002) declares, "The only way of having the evidence about the quality of teaching is to observe a lesson" (p.158). Therefore, observing classroom teaching is one of the organized ways of collecting data for teachers' performance appraisal. Bollington, Hopkins and West (1993) find out that for professional growth of a teacher, classroom observation is to be carried out in a cyclical manner such as, planning conference, classroom observation and feedback conference, which enhance motivation and trust between the appraiser and appraisee. Smith (2002) supports the ideas that teachers get motivated and comfortable with the appraisal process, when the purposes and objectives of appraisal are shared with the appraisee. On the other hand, without sharing the specific areas of job description and sharing post observation feedback make the climate threatening, which may lead the teacher to dissatisfaction and de-motivation. It is the post observation conference that gives opportunities to teachers to talk, inquire and reflect on their practices (Zepeda, 2006).

However, as said earlier, in traditional way of classroom observation, where feedback is given at the end, focusing on the weaknesses causes discouragement and dissatisfaction for teachers. Thus, teachers are often dreadful of being observed by others. Murdock (2000) investigates "that traditional observation and feedback session carried out in a close relation to an observer's checklist tend to result in a demotivating list of a teacher's weaknesses" (p.58). Therefore, he emphasizes that one way of making classroom observation more teacher supportive is to maximize teacher input at all stages of the observation process. In this regard, Marriott (2001) emphasizes that the discussion with the teacher should focus on the teaching and not on the person; and it leads to resolve any differences of opinion. Hence, when discussion is shared with the teacher in a constructive manner, it elicits his/her motivation towards work.

\section{Pre-observation, During-observation and Post-observation Conferences}

One of the strategies of carrying out TPA is to follow a pre-observation conference, duringobservation conference and post-observation 
conference, and relevant discussions as well. Moreover, the appraiser should have the expertise of classroom observation skills, particularly when the appraisal is for summative purposes, through which certain decisions are taken, like to give increment, promotion and demotion. Instead of highlighting and criticizing the weaknesses of the teachers, it is suggested that TPA interviews and post-feedback should be given in a positive and constructive manner, so that teachers feel encouraged and motivated towards their job. In different contexts, classroom observation is carried out in different ways and for different purposes.

\section{Role of Peer Evaluation}

In TPA, critical friends and peers play a vital role in the enhancement of knowledge and skills, as they observe each other's activities, particularly classroom teaching, encourage efforts and achievements, and give and receive feedback in the process of teaching and learning. Holmes (2005) states that a sound working relationship with peers can be instrumental in giving constructive feedback on evidenced-based data gathered through different sources, which brings about improvement in teaching and learning. However, studies indicate that peer evaluation and feedback should be for the sake of formative assessment and not summative one (Stronge $\&$ Ostrander, 2006).

In many school contexts, peer evaluation and feedback is not practiced strongly, or they just become formality. Teachers often do not see peer appraisal as a tool for further improvement.

The above-cited literature shows that teachers should be encouraged to support each other in developing their content knowledge and pedagogical skills. For this, good relationships between the appraisers and appraisees are crucial in order to observe each other's lesson and give meaningful feedback. Studies indicate that peer appraisal should not serve for accountability purposes; rather, it has to be a rich source for enhancing professional knowledge and skills.

\section{Teacher Appraisal through Student Performance and Achievement}

Another source of TPA is through evidences of students' performance and achievement. According to Bollington, Hopkins and West (1993), most teachers and administrator are of the opinion that the ultimate purpose of appraisal is to improve students' learning outcome. However, Gene (1990) opposes the idea that student achievement data are not viewed as credible for distinguishing good performance of teachers from bad performance. When teachers' performance is evaluated only on the basis of students' academic achievement, particularly focusing on the annual exam result, it is very problematic. Relying on a single data source especially on annual exam result is not a fair appraisal of teachers' performance. There are many strong influences on students' academic success (Tucker \& Stronge, 2006). Peterson and Peterson (2006) argue that student achievement data are important for teacher evaluation, but they need to be used in conjunction with other data sources such as peer review and the context of learning in a formative way. This is because multiple data sources provide opportunity for the teacher to see his/her strength and weaknesses and reflects where remedial support is required. Peterson and Peterson (2006) further comment that credible student achievement data allow effective teachers to stand out and be acknowledged even in under achieving schools. In this way, teachers can evaluate their performance. 


\section{Conclusion}

Overall, it is implied from the above discussions that teachers' performance should not be evaluated only by using students' academic achievements, as there are other factors, which could influence student results. Instead, the appraiser should rely on evidencedbased data gathered by multiple sources such as, lesson delivery, appraisal interview, students' achievement and contribution to the overall development of the school. Data on teachers' performance must be collected from a variety of sources and perspectives such as students' views, report by colleagues and managers (Murdock, 2000).

\section{References}

Bell, L, (1988). Appraising teaching in schools: a practical guide. London: Routledge.

Bollington, R., Hopkins, D., \& West, M. (1993). An introduction to teacher appraisal. London: Cassell.

Bosetti, L. (1994). Official policy and truncated practice: a need to reconceptualise the evaluation of teachers. School organization, 14(1), 49-61.

Bush, T., \& Middlewood, D. (2005). Leading and managing people in education: London: Sage Publication Limited.

Dimmock, C. (2000). Designing the learningcentered school: a cross-cultural perspective. London: Falmer Press.

Fleming, P., Max, A. (2001). The art of middle management in primary schools. A guide to effective subject year and team, leadership. London: David Futon Publishers.

Gene, V.G., (1990). Using student test score to evaluate teachers. 229-240. In H.D. Linda. \& M. Jason (Eds.). The new handbook of teacher evaluation. Assessing elementary and secondary schoolteachers. California: A Sage Publication Company.
Geraldine, H. (1997). The industrial relations of appraisal: the case of teachers. The European Journal of analysis. Policy and practice, 28 (3). 206-220.

Harvey-Beavis, O. (2003). Performance based rewards for teachers: A literature review, paper distributed at the third workshop of participating countries on OECD Activity "Attracting, Developing and Retaining Effective Teachers", 4-5 June, Athens, Greece. Available from www.oecd.org/edu/teacherpolicy.

Holmes, E. (2005). Teacher well-being. Looking after yourself and your career in the classroom. London: Routledge.

Holly, L. M. (1990). Perspectives on teacher appraisal and professional development. In S. Helen, \& E. John (Eds.), Rethinking appraisal and assessment (pp.100119). Milton Keynes: Open University Press.

Lunenburg, C. F. (1999). Educational administrations Concepts and practices $\left(3^{\text {rd }}\right.$ ed.). Australia: Wadsword.

Marriott, G. (2001). Observing teachers at work. Oxford: Heinmann Educational Publishers.

Mishra, C. R. (2007). Theory of education administration. New Delhi: APH Publishing Corporation.

Monyatsi, P. P. (2006). Motivating the motivators with developmental teacher appraisal. J. Soc, Sci, 13(2), 101-107.

Newton, J. H. (1996). Appraisal from the bottom up: a school approach. Education to day, 46 (2), 38-42.

Peterson, D. K., \& Peterson, A. C., (2006). Effective teacher evaluation. A guide for principal. Thousand Oaks California: A Sage Publication Company.

Poster, D., \& Cyril. (1994). Teacher appraisal: training and implementation $\left(2^{\text {nd }}\right.$ ed.). London: Routledge. 
Rhodes, C, \& Bell. L (1996). The skills of primary school management. London: Roultege.

Richardson, R. (1999). Performance related pay in schools. An assessment of the green papers. A report prepared for the national union of teachers. The London School of Economics.

Sawatzki, M. (2005). Leading and managing staff high performance schools. In D. Brent. E. Linda, \& B. Christopher (Eds.), School leadership in the $21^{s t}$ Century. Developing a strategic approach (pp.93-108). London: Routledge.

Smith, R. (2002). The Primary Headteacher's Handbook. London: Routledge.

Stronge, H. J. (2006). Teacher evaluation and school improvement. Improving the educational landscape. In S.H. James (Eds.), Evaluating teaching. A guide to current thinking and best practice (pp.119). Thousand Oaks: A Sage Publication Company.
Stronge, H. J., \& Ostrander, P. L. (2006). Client surveys in teacher evaluation. In S.H. James (Ed.), Evaluating teaching. $A$ guide to current thinking and best practice (pp.125-151). Thousand Oaks: A Sage Publication Company.

Tucker, D.P., Stronge, H.J. (2006). Student Achievement and Teacher Evaluation. In S.H. James (Ed.), Evaluating Teaching. A Guide to Current Thinking and Best Practice (pp.152-167). Thousand Oaks: A Sage Publication Company.

Zepeda, J. S. (2006). Classroom-based assessments of teaching and learning. In S.H. James (Ed.), Evaluating teaching. A Guide to Current Thinking and Best Practice (pp.101-119). Thousand Oaks: A Sage Publication Company. 